\title{
THE DEVONIAN GAMONEDA SECTION OF SOUTHERN BOLIVIA: NEW BIOSTRATIGRAPHICAL AND PALAEOBIOGEOGRAPHICAL DATA
}

\author{
Patrick R. RACHEBOEUF', Alejandra DALENZ FARJAT', \\ and Bertrand LEFEBVRE'
}

' Université Claude Bernard, Lyon I, UFR Sciences de la terre and CNRS UMR 5565, 43 bd du
11 Novembre 1918, 69622 Villeurbanne, France.
'2 Laboratorios Integrados de las Americas, Av. Mamerto Cuellar, Casilla 727, Santa Cruz,
Bolivia.

Racheboeuf, P.R., Dalenz Farjat, A. and Lefebvre, B. 1998. The Devonian Gamoneda section of southern Bolivia: new biostratigraphical and palaeobiogeographical data. [La sección de Gamoneda, Devónico del sur de Bolivia: nuevos datos bioestratigráficos y paleobiogeográficos]. Revista Española de Paleontología, 13 (2), 175 186. ISSN 0213-6937.

\begin{abstract}
Reconsideration of the Devonian marine lithological succession in the Gamoneda section of southernmost Bolivia evidences that the distinction of the Gamoneda Formation is not justified. Corresponding deposits have to be assigned to the Icla Formation of the central Subandean Zone. Indeed, in the Gamoneda area the local Devonian sequence only differs from that of the typical Icla and Presto areas in the better development of sandy levels. The occurrence of the Lower Devonian Scaphiocoelia boliviensis Zone in the lowermost beds of the section, just above the Santa Rosa Formation, is established for the first time. An eodevonariid chonetoidean brachiopod (Lomaella sp. cf. L. primoris) is recorded for the first time from Bolivia, and a new fissiculate blastoid is described: Brachyschisma ? gamonedensis. The whole fauna allows to establish correlations both with the central Subandean Zone and with the Argentine Precordillera. Discovery of extra Malvinokaffric faunal elements raises again the palaeobiogeographical relationships between these areas.
\end{abstract}

Keywords: Brachiopods, blastoid, biostratigraphy, correlations, Lower Devonian, Subandean Zone, Bolivia.

\section{RESUMEN}

La revisión de la sucesión litológica del Devónico marino en la sección de Gamoneda, en el sur de Bolivia, pone en evidencia que la distinción de la Formación Gamoneda no está justificada, correspondiendo los depósitos a la Formación Icla de la Zona Central Subandina. En efecto, la secuencia marina en la sección de Gamoneda difiere solamente de la Formación Icla en el área tipo, en el espesor y en el mejor desarrollo de niveles de arenisca. La ocurrencia de la Zona de Scaphiocoelia boliviensis del Devónico Inferior, en los niveles basales de la sección, por encima de la Formación Santa Rosa, se establece por primera vez. Se describen el primer representante de la familia Eodevonariidae en Bolivia (Lomaella sp. cf. L. primoris) y una nueva especie de blastoideo: Brachyschisma? gamonedensis. El conjunto de la fauna permite establecer una correlación con la Zona Central Subandina y con la Precordillera Argentina. El descubrimiento de elementos faunísticos extra malvinocafres plantea una vez más las relaciones paleobiogeográficas entre estas áreas.

Palabras clave: Braquiópodos, blastoideo, bioestratigrafía, correlaciones, Devónico Inferior, Zona Subandina, Bolivia.

\section{INTRODUCTION}

Devonian lithological sequence and stratigraphy in the southern Subandean Zone of Bolivia remains still imprecise and poorly known. In this respect, the
Gamoneda section, c. 13 km ENE of Tarijá (Tarijá department, Cercado province; Fig. 1), is mostly interesting because it is undoubtedly one of the best exposed southernmost sections, together with the Sella section, and the Angosto de Alarache section, both close 


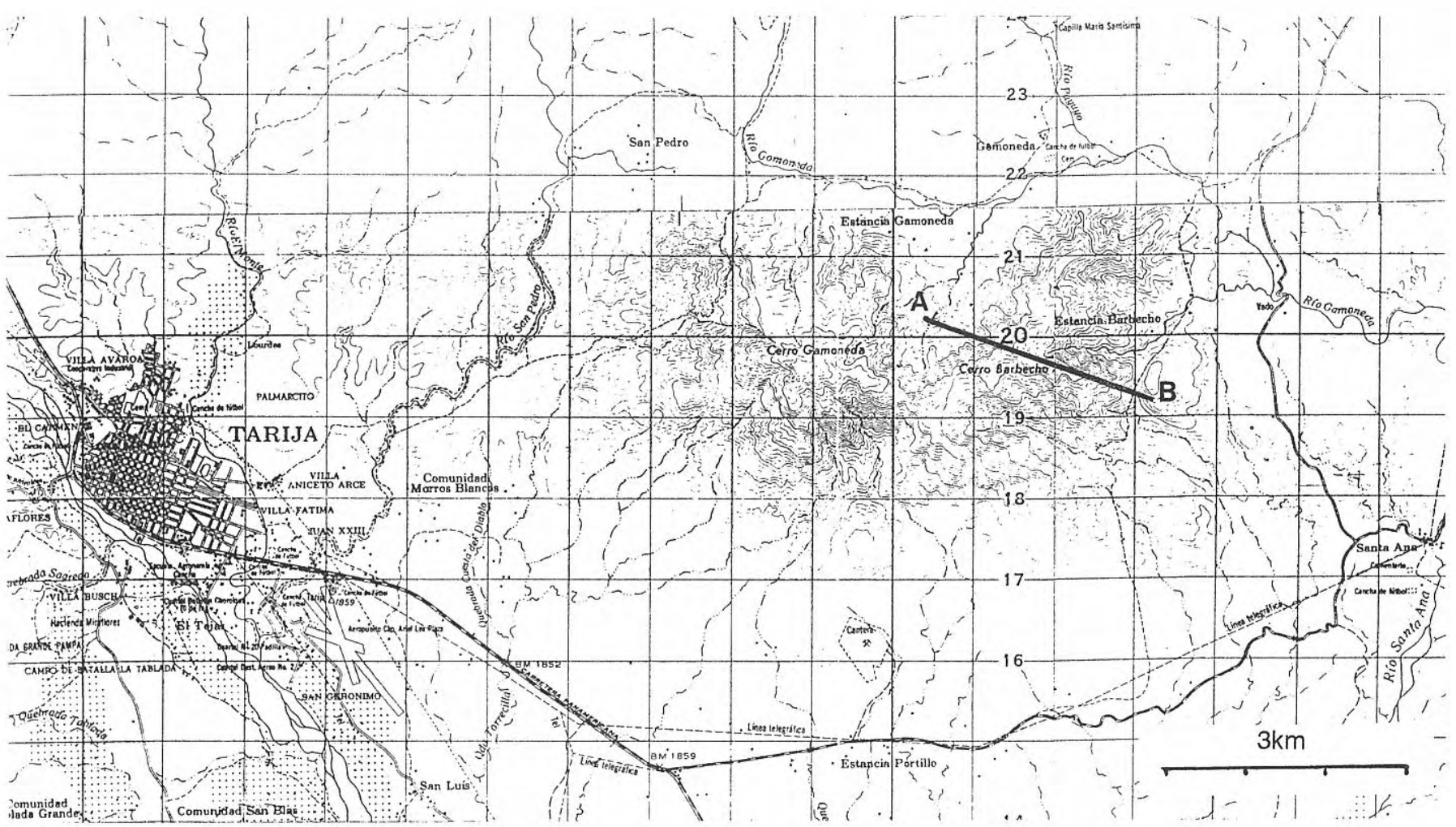

Figure 1. Geographic location of the Gamoneda section, east of Tarijá, in southern Bolivia. After the sheet Tarijá of the Carta Nacional, Bolivia 1:50.000.

to the frontier with Argentina. Known for more than thirty years (Branisa, 1965), the Gamoneda section was briefly described by Isaacson who gave, for the first time, a geologic sketch map and a geologic cross section of the Gamoneda region (1977a, text-figs 19-20). The Gamoneda section was selected as the type of the Gamoneda Formation, a lithostratigraphic unit named by Branisa (personnal communication to Isaacson, 1972), and firstly described by Isaacson (1977a, p. 144-146). According to this author (p. 144), the definition of a new stratigraphical unit was necessary mainly because 'Considerably siltier than its correlatives, the Belén and Icla Formations, the Gamoneda Formation is much thinner overall'. We should not follow Isaacson's interpretation herein and we should consider the so-called Gamoneda Formation to be no more than a lateral variation of the typical Subandean Icla Formation, following Suárez-Soruco and Díaz Martínez (1996). In fact, the Bolivian Devonian siliciclastic sequence is as a whole mainly characterized by silty deposits with intercalated sandstones, the development of which is highly variable both geographically and stratigraphically. The development of sandstones is mainly related to the location of the studied area according to the dynamics of the basin, depth, distance to shoreline and to the source of detritals. Such conditions make correlation of sandy members especially difficult between different areas without precise biostratigraphical data, and may explain, in some cases, the description of different, new, lithostratigraphical units.

\section{THE GAMONEDA SECTION}

by P. R. Racheboeuf and A. Dalenz Farjat

According to Isaacson (1977a, p. 145) the thickness of the Gamoneda Formation is about $500 \mathrm{~m}$ in its type locality. The sandstones of the underlying Santa Rosa Formation are overlain by a first silty member which is about $100 \mathrm{~m}$ thick, with about $20 \mathrm{~m}$ of siltstone and intercalated mudstone beds (about $10 \mathrm{~cm}$ thick, every 2 $\mathrm{m})$ at the top. Then a well differentiated sandy member, about $240 \mathrm{~m}$ thick, showing an increase of bedding from $10-15 \mathrm{~cm}$ in the lower $100 \mathrm{~m}$, to $50-80 \mathrm{~cm}$ in the upper half of the sandy member where most beds are crossstratified. Sandstones are overlain by a dark gray, $20 \mathrm{~m}$ thick mudstone unit, devoid of fossils. A covered interval of $120 \mathrm{~m}$ follows (corresponding to the road to $\mathrm{La}$ Yesera), above which are $13 \mathrm{~m}$ of sandstone, then the silty/sandy succession carries on.

\section{LITHOLOGICAL SUCCESSION}

Description of the section needs complements. Two parts have to be distinguished within the silty lower member overlying the Santa Rosa Formation (Fig. 2). The first $20 \mathrm{~m}$ are highly bioturbated and include Zoophycos beds alternating with coquinas. The overlying $70 \mathrm{~m}$ to $80 \mathrm{~m}$ show the progressive development of interbedded sandy beds alternating with mudstones including three main concretion levels of about 1-2 m thick each: the two first, lower, levels yield dark, fossiliferous, siliceous concretions, whilst the third, upper level, yields ferruginous concretions. The upper 


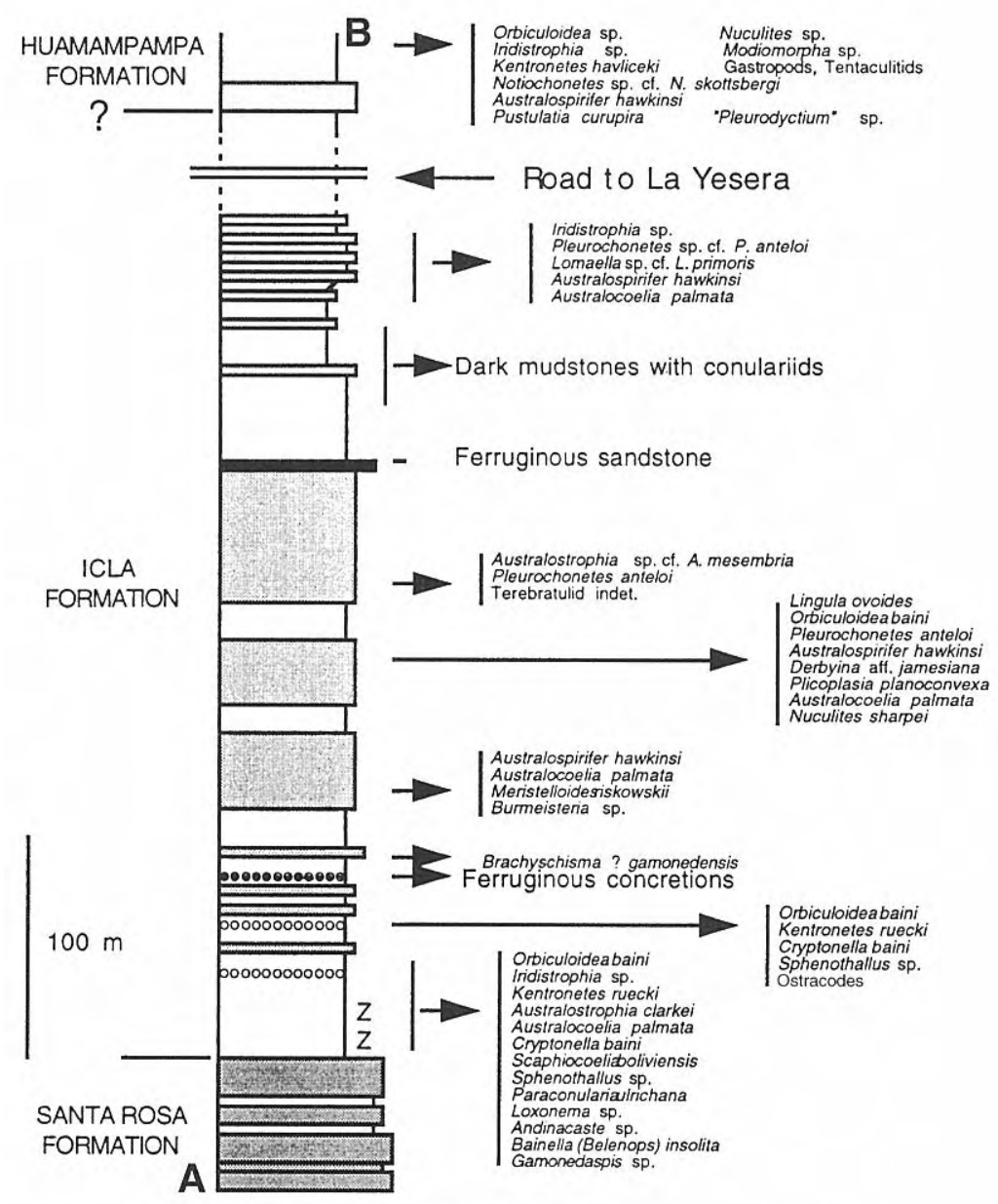

Figure 2. Schematic lithologigal succession of the Icla Formation in the Gamoneda section, and distribution of benthic faunal elements newly collected through the section. Letters A and B refer to the Fig. 1. Z: beds with Zoophycos. Stippled areas correspond to the main sandy levels. Mudstones and siltstones are left in white, whilst ferrugineous levels (concretions and sandstone) are in black.

$20 \mathrm{~m}$ of the sequence include thin interbedded mudstone and siltstone levels. This lower part of the section is highly fossiliferous, and it yields abundant trilobites, brachiopods, ostracodes, etc., as well as the fissiculate blastoid that is described later in this paper.

The overlying sandy member is about $160 \mathrm{~m}$ thick, and it may be divided into three units (Fig. 2). The upper third one is mostly characterized by thick ( $40 \mathrm{~cm}$ to $80 \mathrm{~cm}$ ) crossstratified beds without fossils, with a thick (about $1.20 \mathrm{~m}$ ), massive, brown, iron-rich sandstone level at the top. This ferruginous sandy bed ends abruptly the coarse siliciclastic deposits; it is overlain by $20 \mathrm{~m}$ to $30 \mathrm{~m}$ of dark mudstones. The only fossils found in the mudstones are large conulariids, which have been observed laying obliquely, sometimes almost perpendicular, to bedding planes. This level, as well as the overlying levels of the succession towards the east, can only be observed along the small W-E gullies, which extend eastwards almost to the road to La Yesera. Toward the east, these gullies open in a wider and deeper gully, roughly N-S orientated and subparallel to the road to La Yesera. This part of the section corresponds to the covered interval indicated by Isaacson.

Above the dark mudstones, deposits become coarser and siltstones progressively develop with some sandy, $10 \mathrm{~cm}$ to $20 \mathrm{~cm}$ thick, interbedded levels. This silty member can be estimated to be about $30 \mathrm{~m}$ thick. Close to the junction between the W-E small gullies and the larger N-S one, a fossiliferous silty level, about $2 \mathrm{~m}$ thick, yields brachiopods, among which chonetids and eodevonariids are common.
East of the road to La Yesera sandy deposits become coarser again. A first about $10 \mathrm{~m}$ thick coarse-grained sandy member (top of the lithologic column of Fig. 2; base of the Huamampampa Formation ?) is overlain by a $20 \mathrm{~m}$ thick silty member, then sandstones become progressively coarser and laminated for about $60 \mathrm{~m}$; they yield a rich spiriferid dominated fauna at the top. The succession ends with more than $80 \mathrm{~m}$ thick silty deposits.

\section{BIOSTRATIGRAPHY}

Isaacson (1977a, p. 145) assigned a 'Late Siegenian through mid-Emsian' age to the deposits of the Gamoneda section, and he noted the lack of the characteristic first Lower Devonian Scaphiocoelia Zone biostratigraphic unit. Moreover he considered that the lack of Scaphiocoelia as well as that of other mutationellids which are '...characteristic lower intertidal brachiopods.' was a consequence of deeper environmental conditions. The author wrote that the occurrence of abundant Zoophycos, '...especially in the lower siltstone beds, signify at least a shallow subtidal depth assignment.' (p. 146). In the lower silty member of the section, Isaacson found Australocoelia palmata (Morris and Sharpe), Australospirifer hawkinsi (Morris and Sharpe) and Cryptonella baini (Sharpe), while the sandy member yielded A. palmata, A. hawkinsi, «Schuchertella», Protoleptostrophia concinna (Morris and Sharpe), Australostrophia, Plicoplasia planoconvexa (Knod), Pustulatia curuspira (Rathbun) and Derbyina jamesiana (Rathbun) (Isaacson, 1977a and b). 


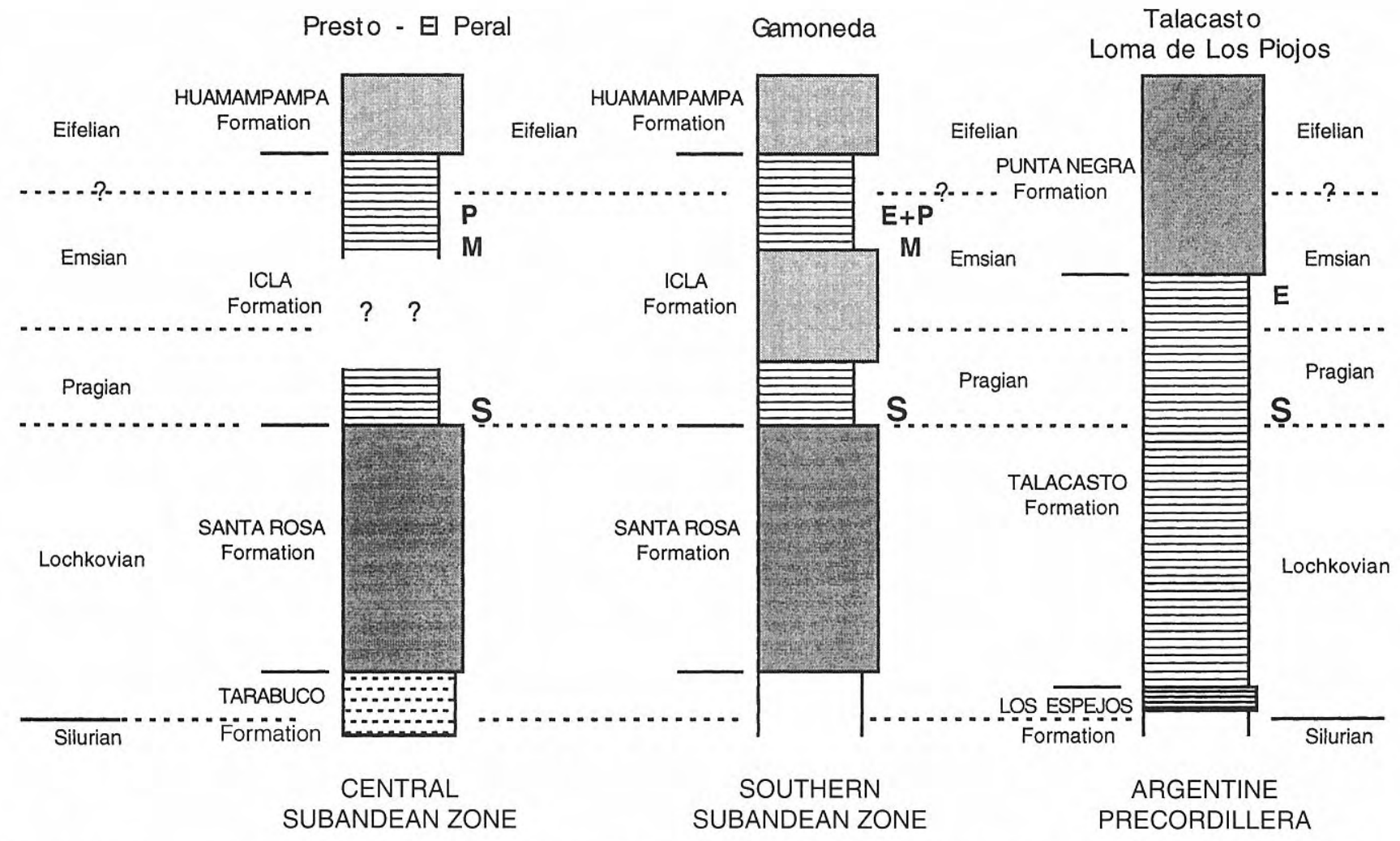

Figure 3. Compared successions and correlations proposed between the Gamoneda section (southern Subandean Zone), the Presto-El Peral section (central Subandean Zone), and the Argentine Precordillera (Talacasto and Loma de Los Piojos sections). In a first rough approximation the lower sandy member of the Gamoneda section probably correlates with the «upper Pragian-Lower Emsian» gap of the Presto area. Dark stippled areas indicate coarse detrital deposits without marine benthic fauna (Santa Rosa and Punta Negra formations) S: beds belonging to the Scaphiocoelia boliviensis Zone. P: large shells of Pleurochonetes anteloi group ; E: Eodevonariidae; M: Maurotarion racheboeufi.

Lithology - Horizontal hachured areas: mudstones and siltstones. Thickened horizontal hachured area: topmost red beds of the Los Espejos Formation. Broken lines: micaceous sandstone. Stippled areas: sandstones (dark stippled areas: fluviatile or deltaic sandy deposits). White: mudstones.

The two visits the authors made to the Gamoneda section, respectively in 1993 and 1994, allowed them to collect an abundant and diversified benthic fauna, among which are faunal elements which had not been found before. They are listed on figure 2. Among these new faunal components, the brachiopods Scaphiocoelia boliviensis Whitfield, Kentronetes ruecki (Ulrich), and Australostrophia clarkei (Racheboeuf and Herrera), as well as the trilobite Bainella (Belenops) insolita Wolfart, are restricted to the Scaphiocoelia Zone. The occurrence of this fauna in the dark, silty lower member of the section, clearly demonstrates that there is no gap within the stratigraphical record which is complete above the Santa Rosa Formation. The occurrence of typical faunal components of the Scaphiocoelia Zone, among which its fossil index $S$. boliviensis, indicates that the environmental conditions were 'normal', i.e. shallow, belonging to the intertidal zone, and not deeper like previously deduced from the lack of mutationellids. The age is likely lower Pragian.

In a recent paper one of us (Dalenz Farjat, in Limachi et al., 1996) gave two distinct ages for the Scaphiocoelia Zone, corresponding respectively to the Lochkovian-
Pragian and Pragian-Emsian boundaries (op. cit. p. 192). This fact would clearly suggest that the Scaphiocoelia boliviensis Zone has to be regarded like an ecozone. Indeed, in Bolivia the large terebratulid Scaphiocoelia boliviensis is typically a benthic pionneer faunal element and both its geographical distribution as well as its occurrence in the first truly marine deposits make it a shoreline marker, an environmental index. However, due to recent stratigraphical results, the vertical range of Scaphiocoelia boliviensis has likely to be restricted to the lowermost Pragian. In the northern subandean area of Bolivia (Quiquibey section), as well as in the central subandean zone (Presto-El Peral section), a lower Pragian age was assigned to the $S$. boliviensis fauna according to palynomorphs (Racheboeuf et al., 1993; Limachi et al., 1996, p. 192).

The occurrence of the homalonotid trilobite Burmeisteria sp. (= Burmeisteria $\mathrm{cf}$. B. herschelii in Branisa, 1965, pl. 11), associated with the large athyridid brachiopod Meristelloides riskowskii Branisa ( $=M$. septatus in Branisa, 1965, pl. 33) in the lowermost beds of the first sandy member of the section is in good agreement with Branisa's data. According to Wenndorf 
(1990), large, spiny homalonotids such as Burmeisteria are mainly Pragian-Emsian in age. Such an age span corroborates the lower Pragian age assigned to the underlying Scaphiocoelia Zone beds.

The eodevonariid chonetoidean brachiopod Lomaella sp. cf. L. primoris Herrera occurs in the upper half of the section, in the siltstone beds outcropping in the gullies, W of the road to La Yesera. This form looks more closely related to the species Lomaella primoris rather than to $L$. sanjuanina Herrera, both species from the upper part of the Talacasto Formation of the Argentine Precordillera. $L$. primoris and L. sanjuanina are considered to be lower Emsian in age (Herrera, 1995). Lomaella sp. cf. L. primoris mainly differs from the two precordilleran species by its more anteriorly divergent inner socket ridges and anderidia. The angle between anderidia as well as the angle between inner socket ridges become commonly more divergent with time. Hence this evolutionary tendency would suggest that the Bolivian eodevonariid is younger than the Argentinian representatives of the family, and as a consequence the corresponding fossil-bearing beds of the Gamoneda section are younger than the eodevonariid-bearing beds of the Argentine Precordillera, i.e. probably upper Emsian in age.

East of the road to La Yesera, Notiochonetes sp. cf. $N$. skottsbergi (Clarke) occurs about $20 \mathrm{~m}$ above the top of the sandstone member which probably belongs to the base of the Huamampampa Formation. The co-occurrence of the bivalve Modiomorpha sp., which is typical for the lower part of the Huamampampa Formation (SúarezRiglos, pers. comm.), supports such a lithostratigraphical assignment. In South Africa (Hiller, 1995) N. skottsbergi occurs in the Gydo, Voorstehoek and Tra Tra formations, i.e. a time interval roughly corresponding to the upper (?) Emsian - middle (?) Eifelian. As a consequence the base of the Huamampampa Formation in the Gamoneda section is more probably Eifelian in age. The same age is inferred for the associated chonetoidean Kentronetes havliceki (Racheboeuf and Branisa) the age of which was up to now uncertain.

\section{CORRELATIONS}

In the Oriental Cordillera, east of the Bolivian Altiplano, the typical Scaphiocoelia boliviensis Assemblage Zone occurs within the uppermost beds of the Vila Vila Formation and in the lowermost beds of the Belén Formation in the Ayo Ayo and Belén sections. In the central Subandean area, in the Presto-El Peral section, where numerous specimens of $S$. boliviensis were found in life position, the Scaphiocoelia boliviensis Zone lies within the uppermost beds of the Santa Rosa Formation and the lowermost beds of the Icla Formation. Both occurrences coincide with the first truly marine environment above the deltaic or fluviatile deposits of the Santa Rosa Formation. The location of the $S$. boliviensis fauna in the Gamoneda section is very similar, and a good correlation can be drawn between these sections (Fig. 3). An age very close to the Lochkovian-Pragian boundary, more probably a lower Pragian age, appears likely (Racheboeuf et al. 1993; Limachi et al., 1996).
In the Argentine Precordillera, Scaphiocoelia boliviensis is only known from the southern part of the Devonian basin, East of San Juan (Peralta, 1987). Despite the lack of the index fossil in the northern and central parts of the basin, the Scaphiocoelia Zone could be identified by other associated faunal elements, mainly trilobites (Vaccari et al., 1994). This level can be correlated with the lower part of the lower member of the Icla Formation in the Gamoneda section, as well as with the transition beds between Santa Rosa and Icla formations in the Presto-El Peral section, and other sections (Limachi et al., 1996). Such a correlation makes the Lochkovian truly marine deposits of the lower part of the Precordilleran Talacasto Formation, a lateral equivalent of the deltaic or fluviatile deposits of the subandean Santa Rosa Formation.

The silty beds of the Gamoneda section yield a large chonetid belonging to the genus Pleurochonetes, together with Lomaella sp. cf. L. primoris. This large and characteristic form is very close (and probably conspecific, the differences being considered to be mainly due to different preservation) to Pleurochonetes anteloi (Isaacson) (sensu Racheboeuf, 1992; Plate 2, figs 1-10) from the upper part of the Icla Formation in the Presto section (central Subandean Zone), and named Pleurochonetes sp. cf. P. anteloi. A second correlation can be tentatively established between these levels of the Gamoneda and Presto sections, respectively. This correlation is warranted by the vertical range of the trilobite Maurotarion racheboeufi Adrain and Edgecombe, 1996 in both areas. According to palynomorphs, an Eifelian age was assigned to the upper part of the Icla Formation in the Presto section (Racheboeuf, 1992; Racheboeuf et al., 1993; Racheboeuf and Isaacson, 1994). This would strongly suggest that Pleurochonetes anteloi ranges from the upper (? uppermost) Emsian to the Eifelian.

\section{SYSTEMATIC PALAEONTOLOGY}

Among the fossils collected from the Gamoneda section and listed in Figure 2, only the new, yet undescribed forms, and newly collected specimens which allow completion of previously described species, are illustrated herein. All listed and illustrated specimens are reposited in the collections of the Laboratorios Integrados de las Americas (ex CTP of the YPFB), Santa Cruz de la Sierra, Bolivia, under numbers YPFB-Pal. Specimens numbered VH... are part of Havlicek's collection housed in Prague.

PHYLUM BRACHIOPODA

ORDER PRODUCTIDA Waagen, 1883

SUBORDER CHONETIDINA Bronn, 1862

Superfamily CHONETOIDEA Bronn, 1862

by P. R. Racheboeuf

Family Strophochonetidae Muir-Wood, 1962

Genus Kentronetes Racheboeuf and Herrera, 1994

Type species: Chonetes ruecki Ulrich, 1893. 


\section{Kentronetes ruecki (Ulrich, 1893)} Figure 4 C-E

v. 1985 Quadrikentron ruecki (Ulrich, 1893); Racheboeuf and Branisa, p. 1429, fig. 2.16-18.

v. 1994 Kentronetes ruecki (Ulrich, 1893); Racheboeuf and Isaacson, p. 104, fig. 5 D, G.

non 1994 Kentronetes ruecki (Ulrich, 1893); Racheboeuf and Isaacson, p. 104, fig. 5 E-F (= Kentronetes iclaense Racheboeuf and Branisa).

\section{Material}

The two external moulds of an articulated shell (YPFBPal 7600), six ventral valve internal moulds, and one dorsal valve internal mould, from the dark siliceous concretions of the lower silty member of the Icla Formation, ca $60 \mathrm{~m}$ above the base of the formation (Fig. 2), among which both external moulds of an articulated shell and one dorsal valve internal mould, respectively YPFB-Pal 7600 and 7601.

\section{Remarks}

Small, juvenile specimens of Kentronetes ruecki are described and illustrated here for the first time. The complete mould of an articulated shell (YPFB-Pal 7600, Fig. 4C-D) is $6 \mathrm{~mm}$ long and $8 \mathrm{~mm}$ wide. Its size and morphology are very close to that of the shell of Babinia parvula Racheboeuf. However their assignment to $K$. ruecki is warranted by the occurrence of typical adult shells in the same beds. It is also warranted by its less transverse outline, its coarser radial ribbing without dorsal median enlarged costa, and costellae increasing by intercalation instead of bifurcation. Moreover, the morphology of spines differs from that of Babinia in their proximal part. The mould of the dorsal valve interior (YPFB-Pal 7601, Fig. 4E) is very close to that of young representatives of Kentronetes variabilis (see Racheboeuf \& Herrera, in press).

\section{Kentronetes havliceki (Racheboeuf and Branisa, 1985) Figure 4 A-B, M-P}

\footnotetext{
v.*1985 Quadrikentron ? havliceki n. sp. Racheboeuf and Branisa, p. 1435, figs. 3.11-3.15.

v. 1994 Kentronetes havliceki (Racheboeuf and Branisa); Racheboeuf and Isaacson, p. 104, fig. 5 K-M.
}

\section{Material}

14 decalcified specimens have been collected in the fossiliferous silty beds, east of the road to La Yesera, about $20 \mathrm{~m}$ above the top of the sandstone which is considered to represent the base of the Huamampampa Formation (Fig. 2). Illustrated specimens are numbered YPFB-Pal 7602 to 7606. The species is associated with Notiochonetes cf. skottsbergi, Pustulatia curupira, Iridistrophia sp.

\section{Remarks}

The discovery of Kentronetes havliceki in the Gamoneda section is of special interest because we know for the first time herein, the stratigraphical location of this rare, or at least uncommon species. The newly collected specimens allow completion of the original description given in 1985 .

\section{Description}

Shell medium size, with maximum width at mid-length. Cardinal extremities obtuse; anterior margin regularly rounded. Shell weakly transverse in outline with a length/width ratio increasing with growth, between 0.69 and 0.80 (mean $=0.73$, for 12 shells between $11.0 \mathrm{~mm}$ and 17.5 $\mathrm{mm}$ long). Longitudinal profile of ventral valve regularly arched from beak to anterior margin; height between onequarter and one-third the ventral valve length. Dorsal valve longitudinal profile regular and weakly concave. Ventral valve surface exhibiting irregular wavy, rugae-like concentric ridges in some specimens. Interareas laying almost in the same plane. Ventral valve interarea relatively long, flat, weakly apsacline to almost orthocline in some specimens. Pseudodeltidium wide, high, strongly convex and prominent. Dorsal valve interarea very short, about onefifth the length of the ventral one, strongly hypercline, with a wide and very low, weakly prominent chilidium. Ornamentation with ventral enlarged median costa restricted to the posterior half of the valve. Low, rounded radial ribs, increasing by bifurcation and intercalation in both valves. Costellae number 13 to 16 per $5 \mathrm{~mm}$ along the anterior shell margin. Spines typical for the genus. Three pairs of spines observed; probably up to 5 pairs.

Description of ventral valve interior without any change or complement. The visceral cavity is always well limited.

Dorsal valve interior with a wide and short cardinal process. Cardinal process deeply bilobed internally, the two inner lobes progressively bending dorsally, and tapering

Figure 4. Chonetoidean brachiopods from the Gamoneda section. See Figure 2 for vertical distribution. A-B, M-P: Kentronetes havliceki. A: dorsal side of an articulated shell, showing the large, prominent, pseudodeltidium, YPFBPal 7602, latex mould, x2; B: dorsal valve interior, latex mould, showing the short and laterally widened cardinal process, and the breviseptum, YPFB-Pal 7603, latex mould, x2; M: incomplete ventral valve exterior, latex mould, YPFB-Pal 7604, x 2; N-O: ventral valve internal mould and dorsal valve interior of the same, latex mould, YPFBPal 7605, x 2; P: dorsal valve interior, latex mould, YPFB-Pal 7606, x 2. C-E: Kentronetes ruecki, juvenile specimens. C-D: respectively ventral valve exterior and dorsal side of the same shell, YPFB-Pal 7600, latex mould, x 3. E: dorsal valve interior, YPFB-Pal 7601, latex mould, x3. F: Australostrophia clarkei, ventral valve interior, YPFB-Pal 7607, latex mould, x1.5. G: Australostrophia sp. cf. A. mesembria, incomplete ventral valve exterior, YPFB-Pal 7608, latex mould, x1.5. H-L: Lomaella sp. cf. L. primoris. H-I: incomplete internal mould of an 

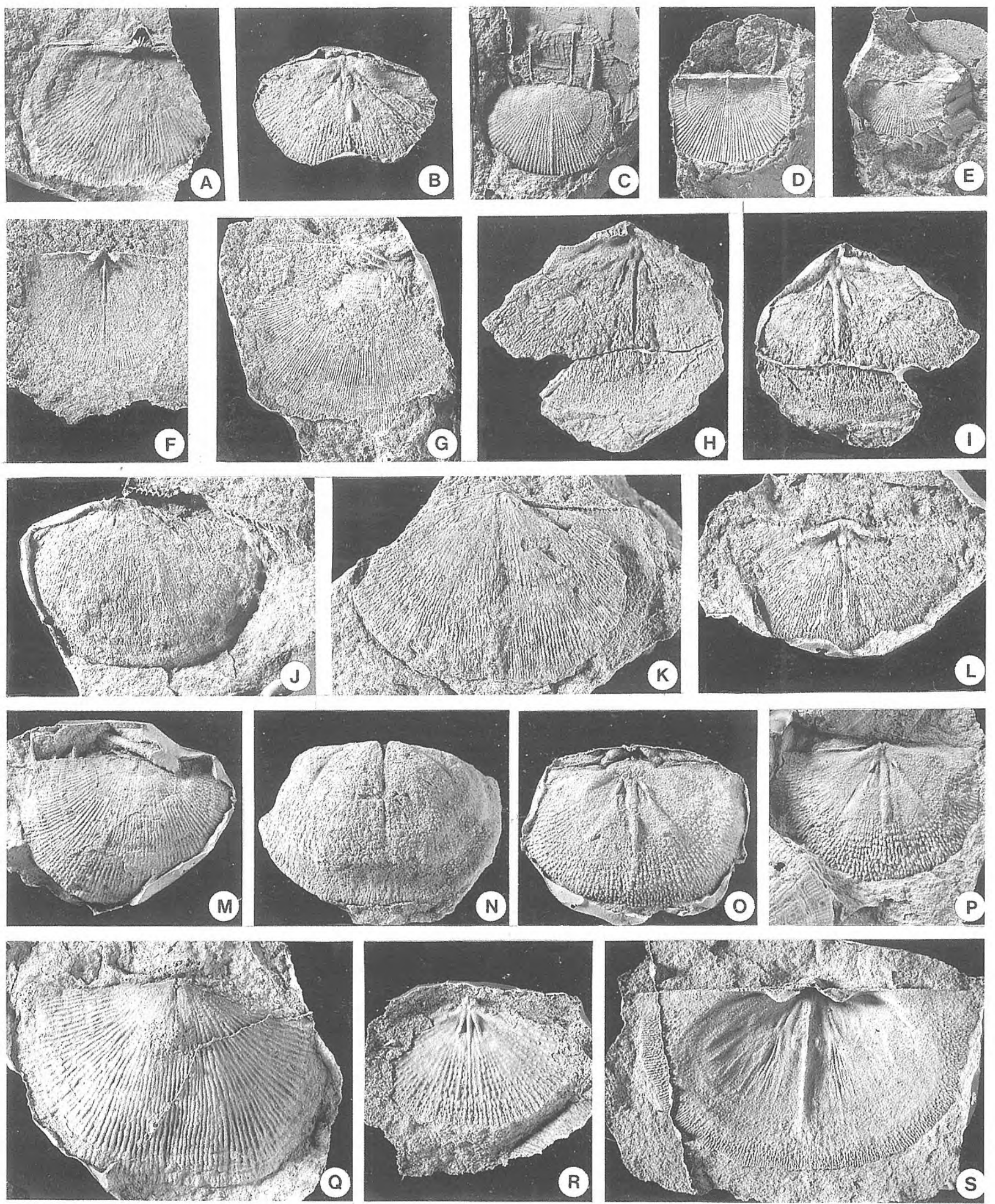

articulated shell, dorsal internal mould and latex mould, YPFB-Pal 7613, x 1.5. J: ventral valve exterior, latex, YPFB-Pal 7614, x 1.5. K: ventral valve internal mould, YPFB-Pal 7615, x 1.5. L: Incomplete dorsal valve interior, YPFB Pal 7616, latex mould, x 1.5. Q-S: Notiochonetes sp. cf. N. skottsbergi. Q: incomplete ventral valve exterior, latex mould, YPFB-Pal 7610, x 1.5; R: incomplete dorsal valve interior, latex mould, YPFB-Pal 7612, x 1.5; S: ventral valve interior, latex mould, YPFB-Pal 7611, x 1.5. 
posteriorly from their junction with inner socket ridges. Myophore relatively large, oblique, posterodorsally oriented. Anderidia relatively short, thick and low, anteriorly divergent at $80^{\circ}$ to $90^{\circ}$. Anterior adductor scars well impressed in the valve floor, and well limited anteriorly. The anterior extremity of the anderidia coincides with half the length of the adductors. Diductor scars well impressed in the valve floor and well limited medially by a well differentiated wall in prolongation of the anderidia.

\section{Comparison}

The newly collected specimens are undoubtedly conspecific with the species $K$. havliceki, as attested by their ventral valve interior (stout vascula media, morphology of hinge teeth and posterior ridges,...), as well as by their dorsal valve interior (very short and laterally widened cardinal process, very broad inner socket ridges, short anderidia, and the development of «a stout [longitudinal] ridge anterior to the typical median septum» (Racheboeuf and Branisa, 1985, p. 1435). However in some specimens, mainly in the smallest ones (see YPFB-Pal 7603, Fig. 4B), these features are not so strongly developed as in the single dorsal valve interior previously known (locality Otorongo, VH 3426; see Racheboeuf and Branisa, 1985, fig. 3-11). Strong development of the breviseptum has to be considered like a gerontic character.

\section{Genus Australostrophia Caster, 1939}

Type species: Leptostrophia ? mesembria Clarke, 1913.

\section{Comments}

Two ventral valves, and one dorsal valve interior moulds undoubtedly belonging to the genus Australostrophia have been found in the Gamoneda section. The ventral valve interior (YPFB-Pal 7607, Fig $4 \mathrm{~F}$ ) was found in the lowermost beds of the section, in the sandy coquina beds intercalated with Zoophycus-bearing beds (Fig. 2). Its size, outline, and inner features favour its assignment to Australostrophia clarkei Racheboeuf and Herrera, 1994, a component of the Scaphiocoelia boliviensis Fauna.

The second specimen (YPFB-Pal 7608, Fig. 4G) is an incomplete ventral valve exterior collected in the lowermost beds of the upper third part of the middle sandy member of the section (Fig. 2). Due to its size, transverse outline, and ornamentation, it can only be tentatively assigned to Australostrophia sp. cf. A. mesembria (Clarke, 1913). An incomplete dorsal valve interior (YPFB-Pal 7609) from the same level also favours such a specific assignment.

Family Chonetidae Bronn, 1862 Subfamily Notiochonetinae Racheboeuf, 1992 Genus Notiochonetes Muir-Wood, 1962

Type species: Chonetes skottsbergi Clarke, 1913.

\section{Notiochonetes sp. cf. N. skottsbergi \\ (Clarke, 1913) \\ Fig. 4Q-S}

\section{Material}

Three incomplete ventral valve exterior, one ventral valve interior and one incomplete dorsal valve interior moulds (YPFB-Pal 7610-7612).

\section{Remarks}

Large chonetids (up to $5 \mathrm{~cm}$ wide) from the upper part of the Gamoneda section have been collected on bed planes between 20 and $40 \mathrm{~m}$ above the base of the Huamampampa Formation, east of the road to La Yesera (Fig. 2). The large size of the shells, their outer morphology as well as inner features make them representatives of the genus Notiochonetes. They are questionably assigned herein to Clarke's species $N$. skottsbergi, waiting for detailed comparisons between all species commonly assigned to the genera Notiochonetes and Pleurochonetes (Racheboeuf, in prep.)

\section{Family Eodevonariidae Sokolskaja, 1960}

South American representatives of the Family Eodevonariidae remain rather uncommon, as in the whole Malvinokaffric Realm, and this is enough to justify the description of the first Bolivian eodevonariid representative, although specimens are poorly preserved. The Bolivian representatives of the Family Eodevonariidae have a finely costellate shell, character which allows differentiation from the South American strongly costate species Eodevonaria imperialis Caster, 1939 from Colombia, and from the Sierra de Perijá of Venezuela (Benedetto, 1984). The Bolivian form can also be easily distinguished from Eodevonaria inca described from Peru (Isaacson, 1977a). It can only be tentatively assigned to the Argentinian genus Lomaella Herrera, 1995 , and it can be compared with the species L. primoris and L. sanjuanina (Herrera, 1995).

\section{Genus Lomaella Herrera, 1995}

Type species: Lomaella primoris Herrera, 1995.

\section{Lomaella sp. cf. L. primoris Herrera, 1995} Figure $4 \mathrm{H}-\mathrm{L}$

\section{Material}

Two ventral valve exteriors and three interiors; one dorsal valve exterior and two interiors; one dorsal side of an articulated shell. All specimens are decalcified. Illustrated specimens are YPFB-Pal 7613-7616.

\section{Description}

Shell large and markedly transverse; maximum observed length $=25 \mathrm{~mm}$; corresponding width $=40 \mathrm{~mm}$. Longitudinal profile moderately concavo-convex. Ventral valve interarea low, apsacline, with relatively narrow and prominent pseudodeltidium. Dorsal valve interarea narrow, 
hypercline. Shell surface ornamented with low rounded radial costellae numbering 16 to 20 per $5 \mathrm{~mm}$ along anterior margin. No spines, nor spine bases observed, even on the ventral valve internal moulds.

Ventral valve interior with a well developed myophragm; its length is one-third the valve length. Muscle field typical for the genus with large diductor scars and well differentiated, deeply impressed, oval to sub-rectangular adductor scars. Hinge line denticulate. Denticles number 7 to 9 per $5 \mathrm{~mm}$. Inner surface covered by small, radially arranged endospines.

Dorsal valve interior with well differentiated median septum supporting the cardinal process. Anterior extremity of the median septum located at about two-thirds the valve length. Cardinal process stout, low and wide, and deeply bilobed, with lobes markedly widened postero-laterally. Myophore in postero-dorsal position. Inner socket ridges relatively long, rounded, and narrow, low-angled with respect to hinge line, anteriorly divergent at about $140^{\circ}$. Relatively stout anderidia, anteriorly divergent at about $50^{\circ}$. Accessory brevisepta well developed. Inner surface covered by numerous, radially arranged, and variably fused, endospines.

\section{Comparison}

The lack of externally developed spines, as well as that of canals crossing the ventral valve posterior margin, can be considered like a diagnostic feature because other chonetoidean shells from the same fossiliferous layer have their spines preserved. This fact strongly suggests that the lack of spines on eodevonariid shells is not relevant of taphonomical conditions. The lack of spines, added to the morphology of the cardinal process, and to the morphology of the ventral muscle field make likely the assignment of the Bolivian form to the genus Lomaella, although it cannot yet be definitely established. Comparison with the Argentinian species indicates that Bolivian specimens share characters both with $L$. primoris and L. sanjuanina. About the external ornamentation, the density of costellae (16 to 20 per 5 $\mathrm{mm}$ ) is closer to L. sanjuanina (16 to 21 ) than to $L$. primoris (20 to 25 ). The number of denticles along hinge line ( 7 to 9 per $5 \mathrm{~mm}$ ) is more similar to L. primoris (6 to 9) than to L. sanjuanina (10 to 12 ). In L. sanjuanina the cardinal process is higher than wide, whilst it is low, short, and stout in L. primoris. In this respect, the Bolivian form is more closely allied to L. primoris than to L. sanjuanina. Anderidia and inner socket ridges are more anteriorly divergent in the Bolivian form: $50^{\circ}$ and $140^{\circ}$ respectively, instead of $40-45^{\circ}$ and $120^{\circ}$ in the two Argentinian species. The size and outline of the ventral adductor scars, as well as the morphology of the inner socket ridges more closely resemble that of $L$. primoris. The Bolivian form probably represents a distinct species, but it is better provisionally left in open nomenclature

PHYLUM ECHINODERMATA De Bruguière, 1791 CLASS BLASTOIDEA Say, 1825

by P. R. Racheboeuf and B. Lefebvre
Devonian blastoids from Bolivia are poorly diversified and they are rather uncommon fossils, as they are in all the Southern Hemisphere. The first Bolivian Devonian blastoid record is that of Codaster aff. pyramidalis by Knod (1908). This form is supposed to come from the Sica Sica Formation (Kozlowski, 1923), but the material was unfortunately destroyed during the Second World War (Macurda, 1979, p. 1361). Devonian blastoids from Bolivia have been extensively revised by Macurda (1979) who described and illustrated two fissiculates: Pachyblastus dicki Breimer and Macurda, 1972, Anguloblastus triangularis n. gen., n. sp., and one spiraculate: Eleutherocrinus cassedayi Shumard and Yandell, 1856.

Pachyblastus dicki was initially described from the Bokkeveld Beds of South Africa. In Bolivia it is restricted to the lower Belén Member of the Altiplano, and is probably Emsian in age. Anguloblastus triangularis is up to now a Bolivian endemic, and it is said to occur above the Condoriquiña Quartzite, i.e. in the upper Belén Member of the Altiplano of Emsian-Eifelian age. It was also found in the Scaphiocoelia Zone of the Subandean area, near Zudañez, of probable Pragian age. Eleutherocrinus cassedayi is a Givetian Appalachian form which has been described from Indiana, Kentucky, New York and Ontario. In Bolivia it is actually restricted to the Belén area of the Altiplano where it occurs in the Dipleura dekayi Zone of Givetian age (Racheboeuf et al., 1993), like in North America.

In such a context the discovery of two specimens of a fissiculate blastoid in the Gamoneda section of southern Bolivia, is of highest interest. First, it adds to the dominance of Bolivian blastoid fauna by fissiculates, emphasizing this peculiar character of the Southern Hemisphere blastoid fauna during the Devonian (Macurda, 1979, p. 1361). Second, its assignment to the genus Brachyschisma is another example of very close faunal relationships between Bolivia and the Eastern Americas Realm. Two species were previously known: Brachyschisma corrugatum (the type species) from the Middle Devonian Onondaga (Eifelian) and Tichenor (Givetian) limestones of New York, and B? oostheizeni Breimer and Macurda, 1972 from the Bokkeveld beds of South Africa. Breimer and Macurda (1972, p. 226) considered that the two Bolivian blastoid radials illustrated by Knod (1908) under the name Codaster aff. pyramidalis '... appear very similar to those of a Brachyschisma.' Later, however, Macurda (1979) thought that they most probably belong to one of the two fissiculates he described, namely Pachyblastus dicki Breimer and Macurda, 1972, and Anguloblastus triangularis Macurda, 1979. Whatever will be, they are different from the species described below.

ORDER FISSICULATIDA Jaekel, 1921

Family Orophocrinidae Jaekel, 1918

Genus Brachyschisma Reimann, 1945

Type species: Codaster corrugatus Reimann, 1935. 

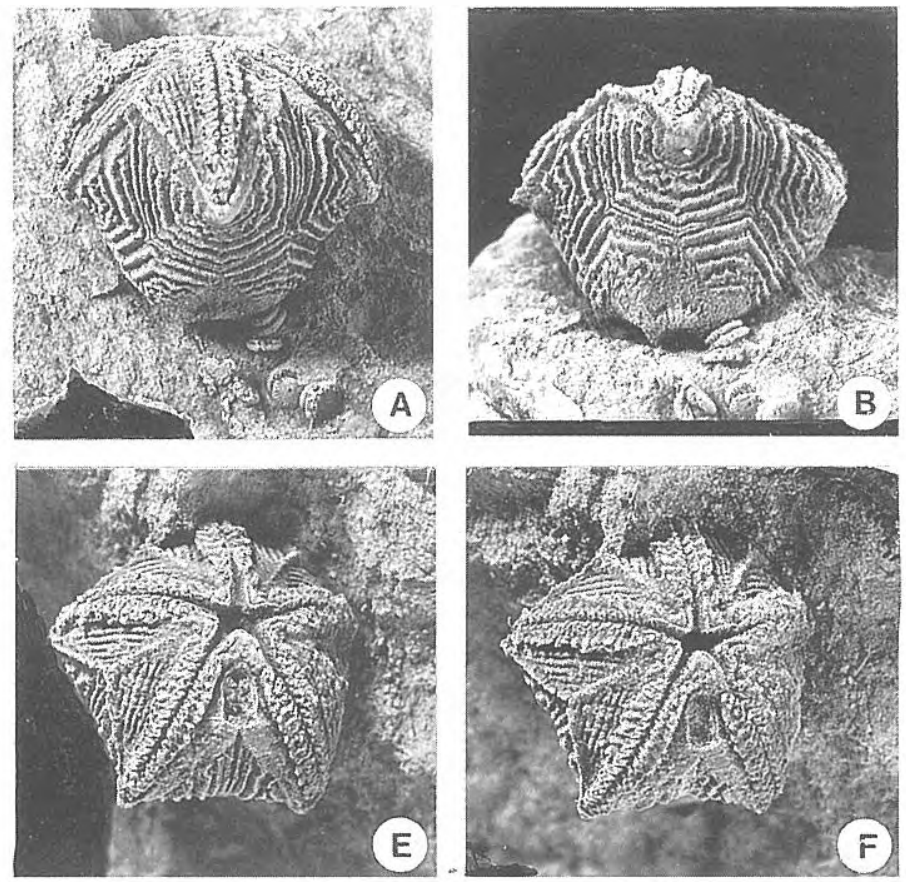
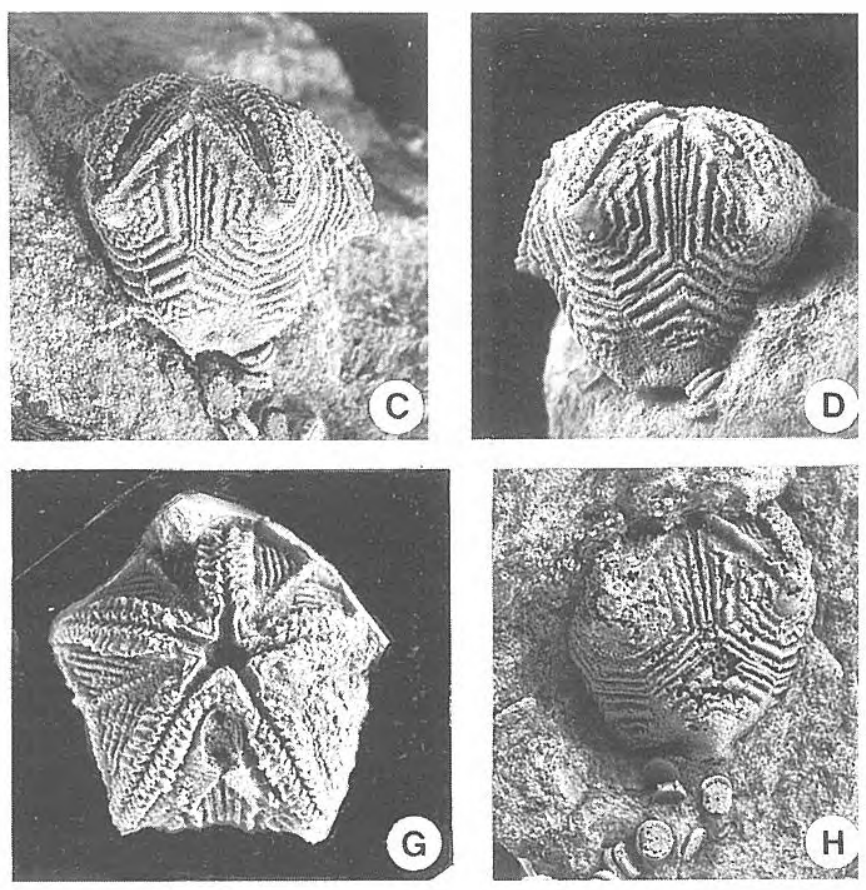

Figure 5. Brachyschisma ? gamonedensis n. sp., Holotype, YPFB-Pal 7617, latex moulds, all figures x 4. A-B: Two lateral (D) views of the theca showing the $\mathrm{D}$ ambulacrum and the ornamentation of the two zygous basalia and the D radial plate. C-D: Respectively DE and CD lateral views. E-G: Three different oral views (anus at 6 o'clock) showing the deltoids and the anal interarea. $\mathbf{H}$ : Lateral $(\mathrm{AB})$ view of the same specimen.

\section{Brachyschisma? gamonedensis $\mathrm{n}$. sp. Figures $5 \mathrm{~A}-\mathrm{H}$}

\section{Derivation of name}

From the Gamoneda section, East of Tarijá, southern Bolivia.

\section{Holotype and material}

Two almost complete, decalcified, thecas on the same slab, the largest of the two being selected here the holotype and illustrated in Fig. 5, the smallest being somewhat distorted. Collection YPFB-Pal 7617.

\section{Type locality and horizon}

Gamoneda section, E of Tarijá (Fig. 1), in the upper part of the lower silty member of the Icla Formation, above the beds with ferrugineous concretions, about $15 \mathrm{~m}$ below the sandstones (Fig. 2).

\section{Diagnosis}

An Orophocrinid species characterized by a relatively rounded theca, with a regularly convex vault; cross section pentagonal to weakly decagonal; pelvic angle close to $100^{\circ}$; hydrospires on regularly convex, not depressed areas; prominent, undulating ridge-like ornament parallel to plate margins.

\section{Description}

Theca conical, relatively wide; pelvic profile conical with relatively broad basalia, slightly convex in lateral view; radials weakly convex in lateral view; no angle between basalia and radials. Pelvic angle close to $100^{\circ}$. Vault moderately, but regularly, convex. Greatest width at ambulacral tips. Ambulacrum $4.3 \mathrm{~mm}$ long; length of interambulacral radius equals $3.3 \mathrm{~mm}$. Cross section almost pentagonal with very weakly indented interambulacral areas. Total length of the theca $7.5 \mathrm{~mm}$; length: width ratio $=0.83$. Pelvis $4.2 \mathrm{~mm}$; vault $3.3 \mathrm{~mm}$; vault:pelvis ratio $=0.78$. For the smallest specimen, which is $7.1 \mathrm{~mm}$ long, the vault:pelvis ratio is about 0.77 .

Basalia three, two zygous and one azygous plates, forming more than one-half of the pelvis, being $2.9 \mathrm{~mm}$ long. $\mathrm{BB}$ margin $2.2 \mathrm{~mm}$ long; BR margin $2.0 \mathrm{~mm}$ long. Base of basals prominent, with three narrow, and short, radial ridges widening and tapering rapidly adorally, alternating with three subtriangular depressed areas. Zygous plates relatively large, hexagonal. Azygous plate quadrangular.

Basals ornamented with coarse, rounded, narrow, prominent, and regular ridges parallel to growth lines, and parallel to BR front; ornamentation reduced to absent along BB margins. Subtriangular, depressed areas, smooth, devoid of any ornamentation. Stem attachment circular, weakly depressed, at the base of the theca.

Radials five, normally arranged, hexagonal with maximum convexity at aboral ambulacrum tip. BR margins 1.9 to $2.0 \mathrm{~mm}$ long; RR margins 3.2 to $3.3 \mathrm{~mm}$ long; RD margins about $1.3 \mathrm{~mm}$. BR margin at $2.6 \mathrm{~mm}$ from origin of growth. Radials divided by a well differentiated, elevated, blade-like ridge, about $1 \mathrm{~mm}$ high at the adoral RR margin. This ridge separates the aboral part of the radial from the adoral part with hydrospires field. Radials ornamented by coarse, narrow, and elevated, U-shaped ridges parallel to growth lines. Ridges undulating, with adoral extremities sometimes deflected externally close to the border of the hydrospires field. 
Deltoids four, quadrangular, and relatively wide, being $2.4 \mathrm{~mm}$ long and about $2 \mathrm{~mm}$ wide. DA margins about 1.9 $\mathrm{mm}$. Deltoids with a radial, well differentiated deltoid crest, fusing aborally with the ridge of the radials, and progressively tapering adorally. Deltoids almost flat, weakly depressed along the interambulacral radius.

Three anal deltoids. Superdeltoid almost indistinct, probably sub-pentagonal. Subdeltoid typically horseshoeshaped. Hypodeltoid not observed, lost, but undoubtedly initially present with respect to the curvature of the inner subdeltoid margin, which suggests a subpentagonal hypodeltoid outline. Anus relatively large, about $1 \mathrm{~mm}$ long and $0.6 \mathrm{~mm}$ wide.

Ambulacrum $5.5 \mathrm{~mm}$ long and about $1.5 \mathrm{~mm}$ wide, with maximum width at midlength. Ambulacrum strongly elevated above the deltoid and radial plates. Side plates small (4 per $\mathrm{mm}$ ). Lancet about $0.7 \mathrm{~mm}$ wide. Median groove about $0.1 \mathrm{~mm}$.

Eight well developed hydrospire fields, each with six hydrospires, the longest hydrospire being along the ambulacrum. Ninth hydrospire field reduced, with only two anal hydrospires present on $\mathrm{C}$ side of anal interambulacral area.

Oral opening pentagonal with concave sides; shorter axis $(1.5 \mathrm{~mm})$ between $\mathrm{A}$ and anal deltoid; longest axis $(1.9 \mathrm{~mm})$ between $\mathrm{B}$ and $\mathrm{E}$ ambulacra.

Stem cylindrical, composed of small stem plates which number 4 per mm. Outer margin of stem plates regularly convex and smooth. Stem plates diametre between $1.0 \mathrm{~mm}$ and $1.1 \mathrm{~mm}$, with a very small axial canal. Diameter of the crenellae circle about $0.8 \mathrm{~mm}$.

\section{Comparison}

Due to the presence of well exposed hydrospires, the new Bolivian form is undoubtedly a member of the Order Fissiculata. Within this order, familial and generic assignment are more delicate to establish. The lack of ambulacral sinuses and interambulacral pyramids precludes the belonging of the Bolivian form to the Family Phaenoschismatidae Etheridge \& Carpenter, 1886, and allows its assignment to the Family Orophocrinidae Jaekel, 1918 (see Breimer and Macurda, 1972, p. 13 and 21). Eight hydrospires are well exposed. Hydrospire group absent on D anal side. On C anal side the subdeltoid plate forms 2 to 3 ill-defined hydrospire slits. Theses characters are in good agreement with the diagnosis of the genus Brachyschisma Reimann, 1945 (See Breimer and Macurda, 1972, p. 22). However the Bolivian specimens exhibit 2 anal deltoids only, instead of 3 as indicated in the diagnosis. The superdeltoid and the horseshoe-shaped subdeltoid are well developed, whilst the hypodeltoid is missing, or atrophied. This may be due to preservation (?) or to some evolutionary trend (?). Due to the lack of an hypodeltoid, the anal side of the Bolivian form somewhat resembles the phaenoschismatid genus Heteroschisma in which the hypodeltoid is atrophied (see Breimer and Macurda, 1972, p. 17), but the new specimens lack the family characters listed above. Moreover the shape and the morphology of the theca, as well as its ornamentation, more closely resemble
Brachyschisma than Heteroschisma. For these reasons the assignment of the Bolivian specimens to the genus Brachyschisma remains questionable, although mostly probable. The fissiculate genus Brachyschisma was up to now restricted to the Middle Devonian of North America (like Heteroschisma), its occurrence in the Bokkeveld Beds of South Africa (Brachyschisma ? oostheizeni Breimer \& Macurda, 1972) being questionable. The Pragian age of the Bolivian form makes it the earliest representative of the genus.

At the species level, the Bolivian form can only be advantageously compared with Brachyschisma corrugatum (Reimann, 1935) from the Middle Devonian Onondaga and Tichenor limestones of New York (see Macurda, 1983). The Bolivian form from Gamoneda differs from $B$. corrugatum by its more rounded general shape, with a regularly convex vault. The pelvic angle is close to $100^{\circ}$, instead of $70^{\circ}-75^{\circ}$. Cross section is pentagonal to very weakly decagonal, instead of markedly decagonal with sharply indented interambulacral areas in B. corrugatum. Hydrospires groups are not located in shallow, concave depressed areas, but are regularly convex in profile. Basals and radials are ornamented with coarse, rugose, prominent, ridge-like, and undulating growth lines, parallel to plate margins. This ornament appears better developed than in the type species. All these characters allow distinction of a new species: Brachyschisma ? gamonedensis.

\section{CONCLUSION}

Preliminary investigations for the revision of the Gamoneda section, E of Tarijá in southern Bolivia, show that : 1/ the lithological nature of the marine deposits as well as their lithostratigraphical arrangement, does not warrant the definition of a regional, distinct formation. The so-called Gamoneda Formation is no more than a southern regional synonym of the subandean Icla Formation. 2/ the faunal inventory needs still to be completed; it is much more diversified than previously established. The fauna is abundant and the recognition of the Scaphiocoelia boliviensis Zone evidences that the biostratigraphical succession is complete within the lower part of the formation, above the underlying Santa Rosa Formation.

From a palaeobiogeographical point of view, the discovery of a new fissiculate blastoid, although questionably assigned to the genus Brachyschisma, adds to the faunal affinities between southern Bolivia and the Northeastern Americas Realm (NEAR) during the Lower Devonian (Pragian) on one hand. On the other hand, the occurrence of the eodevonariid chonetoidean brachiopod Lomaella cf. L. primoris, very close to the two species from the Argentine Precordillera is indicative of faunal relationships between these regions during the Emsian. These two facts bear no contradiction because the Argentine Precordillera shares also strong faunal affinities with the NEAR, among which the occurrence of chonostrophiid chonetoidean brachiopods, for example. 
In conclusion, South American Devonian faunal inventories are far from complete, and further detailed investigations are urgently needed. Detailed, precise correlations, are also necessary to try to explain the palaeobiogeographic evolution and faunal relationships of South American regions, both with the NEAR and with the OWR (Old World Realm). Further detailed biostratigraphical analyses and correlations are necessary for the reconstruction of migratory routes and for the proposal of reliable palaeogeographic reconstructions.

\section{ACKNOWLEDGEMENTS}

Authors are indebted to Dr. D.B. Macurda Jr. who encouraged the study of the blastoid specimens, as well as to Prof. Dr. J. Le Menn (Université de Bretagne Occidentale, Brest), for bibliography support. Prof. Dr. J.L. Benedetto (Universidad Nacional de Córdoba), and Prof. Dr. J. GarcíaAlcalde (Universidad de Oviedo) are fully acknowledged for their valuable comments and their help in improving the manuscript. The Dr. M. Suárez-Riglos (Santa Cruz de la Sierra), and the YPFB Company provided the logistic support for the field work in 1993 and 1994. The field work was a part of the 'Siluro-Dévonien malvinocafre' program of the IFEA (Institut Français d'Etudes Andines, Lima). This institution is greatly acknowledged for its financial support. Photographs by N. Podevigne (UMR 5565, Lyon).

\section{REFERENCES}

Adrain, J. M. and Edgecombe, G. D. 1996. Devonian aulacopleurid trilobites of the Malvinokaffric Realm. Geobios, 29, 417-436.

Benedetto, J. L. 1984. Les brachiopodes dévoniens de la Sierra de Perija (Vénézuela). Biostratigraphie $d u$ Paléozö̈que, 1, 1-191.

Branisa, L. 1965. Los fósiles guías de Bolivia. Servicio Geológico de Bolivia, 6, 1-282.

Breimer, A. and Macurda Jr., D. B. 1972. The phylogeny of the fissiculate blastoids. Verhandelingen der Koninklijke Nederlandse Akademie van Wetenschappen, Afd. Natuurkunde, Eerste reeks, 26 (3), 1-390.

Herrera, Z. A. 1995. The Lower Devonian chonetoidean brachiopods from the Argentine Precordillera, 101-147. In: Four contributions to the study of chonetoidean brachiopods (Ed. P. R. Racheboeuf). Documents des Laboratoires de Géologie de Lyon, 136, 1-238.

Hiller, N. 1995. Devonian chonetacean brachiopods from South Africa. Annals of the South African Museum, 104 (7), 159-180.

Isaacson, P. E. 1977a. Devonian stratigraphy and brachiopod paleontology of Bolivia. Part A, Orthida and Strophomenida. Palaeontographica, A, 155, 133-192.

Isaacson, P. E. 1977b. Devonian stratigraphy and brachiopod paleontology of Bolivia. Part B, Spiriferida and Terebratulida. Palaeontographica, A, 156, 168-217.

Knod, R. 1908. Devonische Faunen Boliviens. Neues Jahrbuch für Mineralogie, Geologie und Paläontologie, Beil Band, 25, 493-600.

Kozlowski, R. 1923. Faune dévonienne de Bolivie. Annales de Paléontologie, 12(1-2), 1-112.

Limachi, R., Goitia, V. H., Sarmiento, D., Arispe, O., Montecinos, R., Díaz Martínez, E., Dalenz Farjat, A., Liachenko, N., Pérez Leyton, M. y Aguilera, E. 1996. Estratigrafía, geoquímica, correlaciones, ambientes sedimentarios y bioestratigrafía del Silúrico-Devónico de Bolivia. Memorias del XII Congreso geológico de Bolivia, Tarijá, 183-197.

Macurda Jr., D. B. 1979. The Devonian blastoids of Bolivia. Journal of Paleontology, 53, 1361-1373.

Macurda Jr., D. B. 1983. Systematics of the fissiculate blastoids. The University of Michigan, Papers on Paleontology, 22, 1-291.

Peralta, S. H. 1987. La posición estratigráfica de Scaphiocoelia boliviensis Whitfield (Brachiopoda) en Devónico inferior de la comarca del río San Juan (Precordillera Sanjuanina), República Argentina. Congreso Latinoamericano de Paleontología, 92-95.

Racheboeuf, P. R. 1992. Los chonetaceos (Braquiópodos) del Devónico boliviano: bioestratigrafía y datos taxonómicos complementarios. Revista Española de Paleontología, 7, 31-52.

Racheboeuf, P. R. and Branisa, L. 1985. New data on Silurian and Devonian chonetacean brachiopods from Bolivia. Journal of Paleontology, 59, 1426-1450.

Racheboeuf, P. R. and Herrera, Z.A. 1994. On some new malvinokaffric Silurian and Devonian chonetacean brachiopods, and reclassification of others. Neues Jahrbuch für Geologie und Paläontologie, Abh., 9, 541560.

Racheboeuf, P. R. and Herrera, Z.A. (in press). Geometric shell growth and mode of life of a Devonian chonetoidean brachiopod. Lethaia.

Racheboeuf, P. R. e Isaacson, P. E. 1994. Los Chonetoideos (Braquiópodos) silúricos y devónicos de Bolivia. Revista Técnica de Yacimientos Petrolíferos Fiscales Bolivianos, 13-14 (1-4), 99-119.

Racheboeuf, P. R., Le Hérissé, A., Paris, F., Babin, C., Guillocheau, F., Truyols Massoni, M. et Suárez-Soruco, R. 1993. Le Dévonien de Bolivie: biostratigraphie et chronostratigraphie. Comptes rendus de l'Académie des Sciences, Paris, 317, II, 795-802.

Suárez-Soruco, R. y Díaz Martínez, E. 1996. Lexico estratigráfico de Bolivia. Revista Técnica de Yacimientos Petrolíferos Fiscales Bolivianos, 17 (1-2), 1-227.

Vaccari, N. E., Waisfeld, B.G. and Edgecombe, G.D. 1994. Calmoniid trilobites of the Lower Devonian Scaphiocoelia Zone in the Argentine Precordillera. Geobios, 27, 591-608.

Wenndorf, K.-W. 1990. Homalonotinae (Trilobita) aus dem rheinischen Unter-Devon. Palaeontographica, A, 211, 1184. 